\title{
Potential Impact of Climate Change on Dynamics of Coffee Berry Borer (Hypothenemus hampi Ferrari) in Ethiopia
}

\author{
Eshetu Agegnehu1 ${ }^{*}$, Ashok Thakur2, Tewodros Mulualem ${ }^{3}$ \\ ${ }^{1}$ Department of Plant Sciences, Faculty of Agriculture, University of Gondar, Gondar, Ethiopia \\ ${ }^{2}$ School of Plant Sciences, College of Agriculture, Haramaya University, Dire Dawa, Ethiopia \\ ${ }^{3}$ Jimma Agricultural Research Center, Jimma, Ethiopia \\ Email: agegnehueshetu@yahoo.com
}

Received 8 January 2015; accepted 24 January 2015; published 27 January 2015

Copyright (C) 2015 by authors and OALib.

This work is licensed under the Creative Commons Attribution International License (CC BY). http://creativecommons.org/licenses/by/4.0/

(c) (i) Open Access

\section{Abstract}

The aim of this paper is to review the potential effect of climate change on dynamics of coffee berry borer and to generate information for researches concerned on it. Coffee (Coffea arabica L.), which is originated in Ethiopia, is the backbone of the country's economy. It accounts for $\mathbf{7 0 \%}$ of the foreign exchange earning, $10 \%$ of the government revenue and employs $25 \%$ of the domestic labor force. There are four coffee production systems in Ethiopia such as modern plantation, gardens, semi-forest and forest coffee. Among the major factors limiting increased Coffee production globally are losses due to pests and estimated to be $13 \%$ worldwide. Over 47 species of insect pests are recorded on Coffee in Ethiopia. Among which Antestia bug, Antestiopsis intricate, A. facetoids and Coffee blotch miner, Leucopteracaffeinia are the major ones inflicting considerable damage as well as insect pests such as Coffee berry borer, Hypothenemus hampei, Coffee thrips, Diarthrothripscoffeae, green scale, Coccusalpinus and Coffee cushion scale, Stictococcusformicarius, are potentially important insect pests in Ethiopia. In addition to pest constraints, Africa are expected to be placed under considerable additional stress by climate change. This is of particular importance for crops such as coffee, which serves as the economic foundation for many countries in the tropics. The Greater Horn of Africa is among the most vulnerable regions to the impacts of climate variability and change. Smallholder coffee farmers are more vulnerable to it, because of various constraints negatively affecting their livelihoods. Climate-induced stress may render plants more vulnerable to opportunistic herbivores. Before 1984, temperatures in the Ethiopian highland's coffee growing regions were cool enough to keep the coffee berry borer in check. However, rising temperatures have enabled several generations of beetles per coffee season. While surveys in 1967 did not show any evidence of coffee berry borers, those conducted in 2003 found that the beetle was widespread in Southwestern Ethiopia. The rise in temperatures and infestation of coffee berry borers may already be affecting Ethiopian coffee crops. From 2002 to 2009, coffee yields plunged by nearly 35 percent. Rising temperatures are threatening the nation's coffee crops by ${ }^{*}$ Corresponding author.

How to cite this paper: Agegnehu, E., Thakur, A. and Mulualem, T. (2015) Potential Impact of Climate Change on Dynamics of Coffee Berry Borer (Hypothenemus hampi Ferrari) in Ethiopia. Open Access Library Journal, 2: e1127.

http://dx.doi.org/10.4236/oalib.1101127 
enabling infestations of insect pests that decrease the quality and yield of coffee berries. Thus, the frequency and severity of climatic extremes are increasing and making adaptation an absolute necessity through using current information on climate variability to develop long term plans for managing coffee berry borer via reducing the vulnerability of Ethiopian coffee growers.

\title{
Keywords
}

\author{
Climate Change, Berry Borer, Dynamics, Coffee \\ Subject Areas: Agricultural Sciences, Plant Science
}

\section{Introduction}

Coffee (Coffea arabica L.), which is originated in Ethiopia, is the backbone of the country's economy. It accounts for $70 \%$ of the foreign exchange earning, $10 \%$ of the government revenue and employs $25 \%$ of the domestic labor force [1]. The Ethiopian economy depends heavily on coffee production. Coffee exports accounted for 21 percent of the country's export income in coffee in 2010, compared with an average of 65 percent in the 1990s, before a global decline in coffee prices [2].

Seventy percent of the coffee is produced as garden coffee by small farmers, $25 \%$ is collected in forest and semi-forest coffee systems, and merely $5 \%$ is plantation coffee [3]. Arabica Coffee grows under very diverse environments including altitude (550 - $2600 \mathrm{~m})$, annual rainfall $(1000$ - $2000 \mathrm{~mm})$ [3]. Major and medium growing woredas contain an estimated 800,000 coffee farmers with approximately 520,000 ha under coffee, of which 63.3 percent is in Oromiya, 35.9 percent in SNPP and 0.8 percent in Gambela. Smallholder producers are responsible for about 95 percent of production, while state-owned plantations account for 4.4 percent and private investor plantations 0.6 percent [4].

Among the major factors limiting increased Coffee production worldwide are losses due to pests (insects, disease, nematodes and weeds), both indigenous and exotic. Insect pests are the most serious and the most numerous, with over 900 species having been recorded [5]. Among which Antestia bug, Antestiopsis intricate, A. facetoids and Coffee blotch miner, Leucopteracaffeinia are the major ones inflicting considerable damage. On the other hand, insect pests such as Coffee berry borer, Hypothenemus hampei, Coffee thrips, Diarthrothripscoffeae, green scale, Coccusalpinus and Coffee cushion scale, Stictococcusformicarius, are potentially important pests in Ethiopia [6].

According to FAO [7], agricultural production and the biophysical, political and social systems that determine food security in Africa are expected to be placed under considerable additional stress by climate change. The term global change embraces a range of natural and anthropogenic environmental changes. According to Intergovernmental Panel on Climate Change, it is defined is as "Change in climate over time, either due to natural, the aspect of population ecology dealing with factors variability or as a result of human activity”. A $10 \%-20 \%$ decline in overall global crop yields is predicted by 2050 IPCC [8]. This is of particular importance for crops such as coffee, which serves as the economic foundation for many countries in the tropics. Smallholder coffee farmers are vulnerable to climate change because of various constraints negatively affecting their livelihoods [9].

Warming temperatures, combined with past declines in world coffee prices, are threatening Ethiopia's coffee industry - a serious concern, given its importance to the nation's economy. From 1979 to 2005, the Ethiopian highlands saw a warming of about $0.70^{\circ} \mathrm{F}-1.17^{\circ} \mathrm{F}\left(0.39^{\circ} \mathrm{C}-0.65^{\circ} \mathrm{C}\right)$ [10]. The Arabica coffee grown in Ethiopia and Latin America is an especially climate-sensitive crop. It requires just the right amount of rain and an average annual temperature between 64 degrees Fahrenheit and 70 degrees Fahrenheit to prosper. Besides affecting the growth of coffee plants, warmer temperatures are also expanding the range of one of the world's most significant coffee pests: The coffee berry borer [11].

Before 1984, temperatures in the Ethiopian highland's coffee growing regions were cool enough to keep the coffee berry borer in check. Since 1984, however, rising temperatures have enabled several generations of beetles per coffee season [11]. While surveys in 1967 did not show any evidence of coffee berry borers, those conducted in 2003 found that the beetle was widespread in southwestern Ethiopia [12]. Now, there is evidence that a 
warming climate may be linked to one of the major threats facing the coffee industry in Ethiopia and elsewhere [13].

The rise in temperatures and infestation of coffee berry borers may already be affecting Ethiopian coffee crops. From 2002 to 2009, coffee yields plunged by nearly 35 percent [14]. Rising temperatures are threatening the nation's coffee crops by enabling infestations of insect pests that decrease the quality and yield of coffee berries [15]. Recent scientific evidence suggests that the frequency and severity of climatic extremes is increasing, making adaptation an absolute necessity. Adaptations such as diversifying crops [16] and using recent information on climate variability to develop long term plans for managing them may help reduce the vulnerability of Ethiopian coffee growers to continued changes in temperature and rainfall. Therefore, this paper is prepared to review the potential effect of climate change on dynamics of coffee berry borer and to generate information for researches concerned on it.

\section{Coffee Production Systems in Ethiopia}

Ethiopia is the primary center of origin and genetic diversity of Coffee (C. Arabica L.). Arabica Coffee grows under very diverse environments including altitude $(550$ - $2600 \mathrm{~m})$ and annual rainfall $(1000$ - $2000 \mathrm{~mm})$. There are four types of coffee production systems in Ethiopia: forest coffee, semi-forest coffee, garden coffee and plantation coffee. These four production system mainly due to varying level of plants associated with coffee, nature of coffee tree regeneration and human intervention in coffee production system [3].

Forest with wild Arabica Coffee populations occur in the southeastern and southwestern highlands of Ethiopia mainly at altitudes between 1000 and 2000 m.a.s.l. [17]. By far the greatest amount of coffee in Ethiopia is derived from spontaneous forest coffee. Forest coffee accounts for about $10 \%$ of the total coffee production in Ethiopia [18].

Semi-Forest Coffee production system is also found in the Southern and South-Western parts of the Country. Farmers thin and select forest trees so as to let in adequate sunlight to the coffee trees and still provide adequate shade. Farmers slash the weeds once a year to facilitate harvesting of the coffee beans. This system accounts for about 35\% of the coffee production [18]. Coffee trees under this category are managed with little cultural practices, such as weeding and shade regulation. These are found in Illubabor, Jimma, Kefa, Bench-maji and west Welega zones. Garden coffee is found in the vicinity of farmers' residences. It is found mainly in the Southern and Eastern part of the country (Sidamo, Gedeo, South and North Omo, Hararghe, Wolega and Gurage Zones, East and West). It accounts for about $50 \%$ of the total production. This production system is on the increase as it is currently being introduced in South West Ethiopia (Kaficho,Shekicho and Bench-Maji) [19].

Plantation coffee is grown on plantations owned by the state (currently put up for sale/privatization) and on some well managed smallholders coffee farms. In this production system, recommended agronomic practices like improved seedlings, spacing, proper mulching, using manure, weeding, shade regulation and pruning are practiced. It accounts for about $5 \%$ of the total production [18]. These large scale plantation (state coffee farms) of about 21,000 hectares are distributed into seven different farms in Limu, Tepi and Bebeka areas [19].

\section{Insect Pests of Coffee in Ethiopia}

Although Ethiopia is the homeland for Arabica coffee and the environmental conditions are suitable for Coffee production, the average national yield is very low. Insect pests are among the factors considered to limit coffee production in both quality and quantity. Over 47 species of insect pests are recorded on Coffee [20]. Insect pest problems are more pronounced in intensive coffee production system (plantation) compared to garden and semi forest coffee production systems mainly due to changes in cultural practices associated with the newly planted cultivars [6].

\section{Key Insect Pests of Coffee in Ethiopia}

Among totally forty-seven insect pests of coffee were reported only two insect pests Antestia bugs and Coffee leaf minor are the major insect pests [20]. There are 3 species of Antestia bug, Antestiopsis spp. in Ethiopia, namely A. intricate (Ghesquiere and Carayon), A. facetoides (Greated) and A.orbitalis Carayon. A. intricate is the most common bug found in all coffee growing areas except Hararghe, where only A. facetoides is found. Weather factors, host plant, and natural enemies may be attributed for distribution and seasonal changes in population of the insect [20]. There are two species of Coffee blotch miner, Leucoptera spp, attacking Coffee leaves, 
namely, L. meyricki (Ghesquier) and L. caffeine Wash bourn. The latter is the most important, commonly occurring in shaded Coffee [6].

\section{Potentially Important Insect Pests of Coffee in Ethiopia}

Coffee berry borer, Hypothenemus hampei (Ferrari) population had a marked seasonal variation both on dry left over and fallen berries. Moreover, weather factor showed a marked influence on its population dynamics. In Ethiopia it attacks only dry left over and fallen berries. Damage on green berries was almost negligible $(<1 \%)$ [20]. Coffee scale insects, out of the seven species of scale insects recorded on Coffee in Ethiopia, Coffee cushion scale, Stictococusformicarias New stead and green scale, Coccusalpinus De Lotto are potentially important pests. Both species are also present in Jimma but at a low level of infestation [21].

\section{Global History of Coffee Berry Borer (Hypothenemus hampei)}

The coffee berry borer, Hypothenemus hampei Ferrari (Coleoptera: Scolytidae) is the most serious pest of commercial coffee in virtually all producer countries of the world. Hypothenemus hampei was first recorded in coffee seeds of unknown origin being traded in France in 1867 [22] and first reports of the pest in Africa were from Gabon in 1901 and Zaire in 1903 [23]. However, the true origin of this pest remains unclear.

Evidence is that $H$. hampei is not found above $1500 \mathrm{~m}$, which is the preferred altitude of Arabica coffee, which originates from Ethiopia. Robusta coffee, from West and Central Africa, being found at lower altitudes, is therefore more likely to be the original host of the pest [24]. However, differing opinions concerning the geographical origin of the pest have been presented. Murphy \& Moore [23] who proposed two scenarios; that either $H$. hampei itself originated from North East Africa, the original home of Arabica coffee, or, that Arabica coffee was contaminated in Ethiopia or Saudi Arabia (where it was first imported for cultivation at some unknown date before the 15th century) by the passage of infested berries of West African Robusta coffee through the area.

The suggestion that the original host of $H$. hampei was C. canephora was initially strengthened by the report from Davidson [25] who concluded that the pest was absent from Ethiopia, the home of Arabica coffee. Apart from a few reports of characteristically damaged berries from the southwest of the country, there was no further mention of H. hampei in Ethiopia until Abebe [26] reported the pest to be present at all but one of the sites studied. The borer was found at all altitudes from below $1000 \mathrm{~m}$ to over $1900 \mathrm{~m}$, in the major coffee-growing areas in the south and south-west of the country, with relatively higher infestation at lower altitudes.

\section{Biology and Ecology of Coffee Berry Borer (Hypothenemus hampei)}

The family Scolytidae can be divided into two main subdivisions; the sub-cortical feeders or bark beetles and the woodborers or ambrosia beetles, which include the genus Hypothenemus. Ambrosia beetles live in symbiotic association with fungi that feed on wood and are then in turn fed upon by the beetle which may never directly feed upon the wood itself [27].

The coffee berry borer is a small beetle measuring $2 \mathrm{~mm}$ in length [24]. Briefly, according to Barrera [28], the synovogenic female lays between 31 and 119 eggs within a single coffee berry of suitable ripeness and the life stages consist of the egg, larva, pupa (with a brief pre-pupal stage) and adult (Figure 1). The juvenile stages last for an average of 4 (egg), 15 (larva) and 7 (pupa) days, respectively, at $27^{\circ} \mathrm{C}$. The complete life cycle may take from 28 to 34 days. Reports of the life expectancy of the adults are varied; males may live for $20-87$ days and females for an average of 157 days [28]. Where coffee is present all year round, as occurs in Uganda, H. hampei may exceed eight generations a year. Hypothenemus hampei feeds on and reproduces in the endosperm of the seed of the coffee berry, burrowing through exocarp, mesocarp and endocarp to reach it, which may take, under optimum conditions, up to 8 hours [27].

In the inter-harvest or dry season, female $H$. hampei remain semi-inactive in old berries waiting for the first rains which stimulate females to emerge and search for new berries in which to begin the next cycle [28]. The rain itself is not the trigger, the coffee berries simply become waterlogged and uninhabitable. An extended dry season can reduce $H$. hampei infestations due to the sensitivity of the scolytid to humidity levels up to 150 adults may be found in a single berry during the inter-harvest period, as reproduction continues until the resources are totally exhausted [24]. 


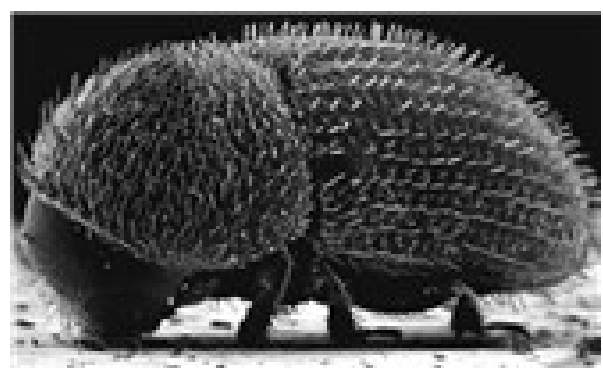

Figure 1. Adult coffee berry borer beetle.

Waterhouse and Norris [22] stated that a female $H$. hampei can live for 81 days without food. The pest becomes inactive below $15^{\circ} \mathrm{C}$, very close to the lower end of the temperature range of the coffee plant at $16^{\circ} \mathrm{C}$ [27]. Female $H$. hampei mate a few hours after emergence with sibling males, which have reduced degenerate wings and do not leave the berry. Twelve days after hatching, the phototropism of the female inverts and the female emerges from the berry during the hours of maximum sunlight. Dissemination of the pest is generally considered to take place by long and short distance flight, passive transport (animals, vehicles, humans, wind, etc.) and the coffee trade [27].

\section{Damage Caused by Coffee Berry Borer (Hypothenemus hampei)}

Hypothenemus hampei is a pest of immature and mature coffee berries, causing no damage to the leaves, branches or stem. Hypothenemus hampei (Ferrari) is the only species that directly attacks the seed [29]. Adult female $H$. hampei bore galleries into the endosperm of the coffee seed, causing three types of economic losses (Figure 2): 1) boring and feeding activities of adults and progeny cause a reduction in yield and quality of the final product 2) due to physical damage, attacked mature berries become vulnerable to infection and further pest attack and 3) when insufficient mature berries are available, i.e. at the beginning of the season or where frequent harvesting is practiced, the hard, green berries are attacked. Although unsuitable for breeding, the female beetle often makes abortive attempts to bore into these berries causing premature fall, arrested development or decay [30]. The lesions caused by the activity of the scolytid create an entry site for secondary infection by bacteria and fungi. Two species of bacteria, Erwiniastewartii (Smith) and E. salicis (Day) Chester (Enterobacteriaceae), have been implicated as the agents responsible for wet rot in the mesocarp of immature berries superficially damaged by $H$. hampei (which had then rejected and left the berries) [27].

\section{History of Coffee Berry Borer (Hypothenemus hampei) Associated with Climate Change}

The coffee berry borer, Hypothenemus hampei (Ferrari) (Coleoptera: Curculionidae: Scolytinae), is the most important biotic constrain for commercial coffee production worldwide [31]. The geographic centre of origin of the coffee berry borer is unknown, but it is probably endemic to central Africa, becoming naturalized elsewhere due to movement of coffee plants and beans through multiple, persistent introductions [32]. Until ten years ago, there were no reports of $H$. hampei found attacking coffee plantations above $1500 \mathrm{~m}$, which is within the preferred altitude range of cultivated and naturally occurring C. arabica (1400 - 1600 and 1200 - 2000 m.a.s.l., respectively).

The original host of the coffee berry borer was probably $C$. canephora a species naturally occurring and cultivated at lower altitudes (250 - 1500 m.a.s.l.). However, due to recent increasing temperatures in coffee growing regions in the world, the insect can now be found also at higher altitudes, where it able to infest $C$. arabica. It is unknown if $C$. arabica and $C$. canehora are the only host plants of $H$. hampei. Other Coffea species, or perhaps even other genera of indigenous Rubiaceae, which both occur in large numbers in the understory of forests in Africa, are also attacked by the coffee berry borer under natural conditions [11].

There are many reports of feeding, with occasional reproduction, in plants of the Fabaceae family and reports of three Rubiaceae species where feeding and reproduction of the borer has taken place [31], but no detailed studies on life table parameters of the borer on those plants have been conducted. The coffee berry borer attacks the beans, which are the marketable product, causing losses exceeding US \$500 million annually, and worldwide affects many of the more than 25 million rural households involved in coffee production [29]. Under low pest pressure 


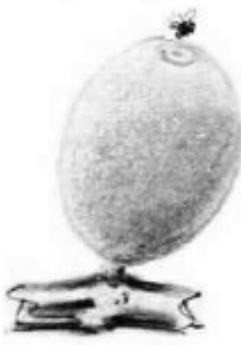

(a)

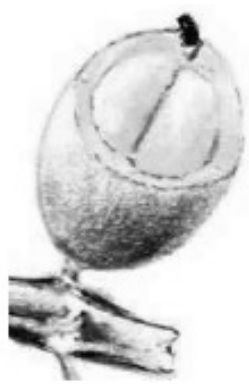

(b)

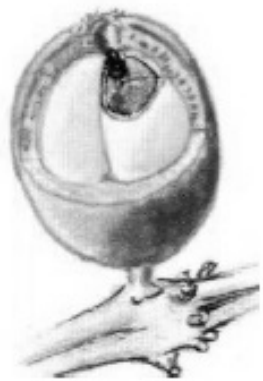

(c)

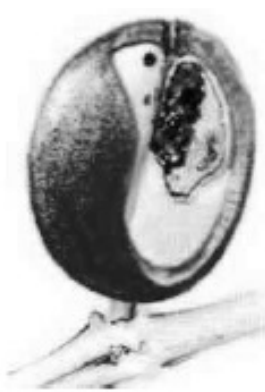

(d)

Figure 2. Adult Beetle entering and attacks the coffee berry.

the conversion factor (i.e. after processing, the amount of parchment coffee obtained from a given amount of freshly picked coffee berries) is 5:1; however, a serious $H$. hampei infestation can alter this ratio up to $>17: 1$, with devastating economic consequences for farmers [24]. Currently, $H$. hampei is present in all coffee producing areas of the world, except China and Nepal, with the most recent introductions to Puerto Rico in 2007 and Hawaii in 2010.

Earlier predictions on the effects of climate change on coffee and the coffee berry-borer estimated that even a small increase in temperature would have serious consequences for coffee production, including plantations in Brazil, Mexico and Uganda, in some cases rendering production very difficult [33]. Particularly serious consequences are predicted for the areas where high quality C. arabica is produced [11]. Jaramillo et al., [11] predicted that a $1^{\circ} \mathrm{C}$ increase would lead to a considerably faster development, higher number of generations per fruiting season and a shift in the geographical range for H. hampei. Furthermore, the model by Jaramillo et al., [11] predicts that even higher temperatures would result in shifts in the pest's latitudinal and altitudinal range.

Yet, it seems that this erstwhile worst case scenario is already happening, as changes in the altitudinal range of H. hampei have recently been observed in Indonesia and Uganda; moreover, on the slopes of Mt. Kilimanjaro in Tanzania the coffee berry borer is now found at elevations 300 meters higher than those at which the insect was present ten years ago [34]. Overall, the situation is forecasted to worsen in the current $C$. arabica producing areas of Uganda, particularly around the eastern side of Lake Victoria and Mt. Elgon. Likewise, the climatic suitability for coffee berry borer is predicted to increase in southwest Ethiopia, the most important core area for the natural distribution of C. Arabica [35].

\section{Climate Change and Its Potential Effects on Dynamics Coffee Berry Borer (Hypothenemus hampei) and Coffee Production in Ethiopia}

The Intergovernmental Panel on Climate Change IPCC [8] predicts an increase in the mean global temperature of $1.4^{\circ}$ to $5.8^{\circ} \mathrm{C}$ by the end of the twenty-first century [36] future annual warming ranges from $0.2^{\circ} \mathrm{C}$ to $>0.5^{\circ} \mathrm{C}$ per decade in Africa according to B1 and A2 scenario [37]. Future changes in mean seasonal rainfall in Africa are less well defined. However, in general, models forecast that parts of equatorial East Africa will likely experience 5\% $20 \%$ increase in rainfall from December to February and 5\% - 10\% decrease in rainfall from June to August by 2050. These changes in climatic conditions are also predicted to profoundly influence the population dynamics and the status of agricultural insect pests [37].

Knowledge on thermal tolerance is essential to predict the effects of climate change in an organism [38]. Such information has never been used to predict the effects of climate change, i.e., global warming on the coffee berry borer Hypothenemus hampei Ferrari (Coleoptera: Curculionidae: Scolytinae) the most important pest of coffee throughout the world [31]. For many years, there has been controversy in the literature about the geographic origin of the pest and its original host plant(s) [38]. Based on researches estimate on the thermal tolerance of $H$. hampei it is unlikely that the beetle is endemic to the area around Jimma (Ethiopia) due to the low annual minimum temperatures prevalent there.

During an extensive survey, Davidson [25] did not find H. hampei in Ethiopia and Damon [31] later speculated that the absence of the pest is due to either specialized natural enemies, resistant varieties of $C$. arabica or exceptionally clean harvest practices in Ethiopian plantations. However, analysis of 32 years of climatic data from Jimma indicate that before 1984 it was too cold for the insect to complete even one generation per year, but the- 
reafter, because of rising temperatures in the area, the pest is now able to complete 1 - 2 generations per year/ coffee season. This may explain why in a more recent study Mendesil et al. [12] reported wide spread occurrence of the coffee berry borer in southwestern Ethiopia.

Campbell et al. [39] emphasized the usefulness of the lower threshold of development and the thermal constant of an insect to elucidate its potential distribution. Similar to C. arabica, C. canephora is an understory tree of lowland forests. Climatological data from shaded coffee plantations in Central America [40] and East Africa Kirkpatrick TW [41] indicate a reduction in temperature between $2^{\circ} \mathrm{C}-6^{\circ} \mathrm{C}$ depending on the region, when compared to coffee grown without shade. Since the two coffee species naturally occur in relative proximity in Central and Eastern Africa [35] it could have been possible that the coffee berry borer actively or passively dispersed from its original host plant C. canephora to the closely related C. arabica. Moreover, in life table studies in the laboratory $H$. hampei performed significantly better on Robusta compared to arabica coffee (J. Jaramillo, unpublished data). Over the last three decades, the average daily temperature per year ranged between $17.3^{\circ} \mathrm{C}$ $22.3^{\circ} \mathrm{C}$ for Ethiopia, $18.7^{\circ} \mathrm{C}-24.5^{\circ} \mathrm{C}$ (data from 1989 to 2007 , as $\mathrm{H}$. hampei was introduced in 1988 into the country). The potential number of $H$. hampei generations per year was in average 1.3 for Ethiopia.

The eco-physiology of both insect and plants will predict the future distribution of insect pests when both host plant and herbivore are in close synchrony. Thus, in the case of a highly specialized herbivore like H. hampei, the effects of climate change on the insect and the plant cannot be separated. Under a climate change scenario, species like $H$. hampei, whose distribution are restricted by both temperature and the availability of their host plants will follow plant distribution [42]. Findings indicate that $H$. hampei can survive and reproduce within a broad temperature regime and that the potential number of generations as an indicator of the pest status varies profoundly with daily seasonal temperature. The lower number of generations found in Ethiopia is probably a result of the lower temperature prevalent in the sampling area. Thus the most appropriate way for coffee production systems to cope with climate change is to come back to the origins of coffee as an understory tree in the forests of Africa.

The thermal tolerance of the coffee berry borer, Hypothenemus hampei, the most devastating pest of coffee worldwide, and make inferences on the possible effects of climate change using climatic data from Colombia, Kenya, Tanzania, and Ethiopia. For this, the effect of eight temperature regimes $\left(15^{\circ} \mathrm{C}, 20^{\circ} \mathrm{C}, 23^{\circ} \mathrm{C}, 25^{\circ} \mathrm{C}, 27^{\circ} \mathrm{C}\right.$, $30^{\circ} \mathrm{C}, 33^{\circ} \mathrm{C}$ and $35^{\circ} \mathrm{C}$ ) on the bionomics of $\mathrm{H}$. hampei was studied. Successful egg to adult development occurred between $20^{\circ} \mathrm{C}-30^{\circ} \mathrm{C}$. Using linear regression and a modified Logan model, the lower and upper thresholds for development were estimated at $14.9^{\circ} \mathrm{C}$ and $32^{\circ} \mathrm{C}$, respectively. Analyzing 32 years of climatic data from Jimma (Ethiopia) revealed that before 1984 it was too cold for $H$. hampei to complete even one generation per year, but thereafter, because of rising temperatures in the area, 1 - 2 generations per year/coffee season could be completed. Calculated data on warming tolerance and thermal safety margins of $H$. hampei for the three East African locations showed considerably high variability compared to the Colombian site. The model indicates that for every 1 degrees centigrade rise in thermal optimum, the maximum intrinsic rate of increase will increase by an average of $8.5 \%$ [11].

The developmental time of $H$. hampei immature stages was significantly influenced by temperature. For egg to adult, the lower developmental threshold was $14.9^{\circ} \mathrm{C}$ and the thermal requirement for completion of the pre-reproductive phase was calculated as $262.47^{\circ} \mathrm{C}$ - days above the lower developmental threshold. Developmental rates increased linearly between $15^{\circ} \mathrm{C}$ and $27^{\circ} \mathrm{C}$ for pre-pupa, pupa and adult, and between $15^{\circ} \mathrm{C}$ and $30^{\circ} \mathrm{C}$ for eggs and L1 [11].

Based on the number of degree-days in the four sites in Colombia, Kenya, Ethiopia and Tanzania, the estimated number of generations of $H$. hampei per year ranged from 0.0 to 4.71 . The number of $H$. hampei generation per year ranged between, 2.03 - 3.13 for Kisii, Kenya. With 0.0 - 2.02 the lowest number of beetle generations per year was estimated for Jimma, Ethiopia. Calculated data on warming tolerance (WT) and thermal safety margins (TSM) of the insect for the three East African locations showed considerably high variability compared to the Colombian site [11]. A tiny insect that thrives in warmer temperatures, the coffee berry borer has been spreading steadily, devastating coffee plants in Africa, Latin America, and around the world. The research, forecasts that, by 2050, the conditions in southwest Ethiopia, known for the highly valued Arabica coffee species, will be much more suitable for the pest (Guardian.co.uk, 2010). Currently, the coffee berry borer is able to complete between 1 4.5 generations in East Africa Jaramillo et al. [11], under both climate change scenarios used in this study, by 2050 the number of generations will have increased to 5 - 10 and 11 - 16 in high (1400 - 1800 m.a.s.l.) and low to middle elevation (900 - 1300 m.a.s.l.) coffee production regions of East Africa, respectively.

The coffee berry borer is already present in East Africa at altitudes > 1800 m.a.s.l Kyamanywa et al. [43] and 
recent reports from Tanzania indicate that the insect has moved up 300 m.a.s.l. during the last ten years Mangina et al. [34]. The coffee berry borer could also be more difficult to control at higher altitudes since moving a pest into a new ecosystem makes its behavior [13]. In addition, the present La Niña event is causing unusually warm and dry conditions throughout East Africa, leading to serious outbreaks of $H$. hampei in the region, for example in Rwanda [44]. Consequently in these areas of East Africa, C. arabica production most certainly will need to be moved to higher elevations. It has been estimated that Colombian C. arabica plantations would have to be moved by $167 \mathrm{~m}$ in altitude for every $1^{\circ} \mathrm{C}$ of increase in temperature, in order to maintain the same productivity and quality [45]. Although these figures cannot be directly extrapolated for East Africa, it gives an idea of the magnitude of a potential distribution shift.

An assisted altitudinal migration of $C$. arabica coffee plantations in East Africa would most probably not be feasible, because of a paucity of available and suitable high altitude habitats in East Africa, and due to rising demographic pressure and issues related with food security that the region is likely to face in the future. Kenya, Uganda, Tanzania, Rwanda and Ethiopia are predicted to experience population increases of $77 \%-110 \%$ by 2050 (Population Reference Bureau, http://www.prb.org). The International Coffee Organization (ICO) predicts that under the A2 and B2 climate change scenarios, coffee production will decrease by up to $10 \%$ compared to the reference case without climate change [46].

Recent studies suggest that climate change will not only influence plant performance, but also its interactions with other trophic levels, consequently affecting the abundance of the species [47]. For example, decoupling of the coffee berry borer and its natural enemies could result in higher pest numbers or more serious outbreaks. Presently, nothing is known about the effects of a warming climate on the natural enemies of the coffee berry borer, yet, higher trophic levels are often disproportionately affected by drivers like climate change and habitat modification, with specialist natural enemies (parasitoids) more hit than generalists (predators) [48]. Between 2009 and 2011, C. arabica prices have increased by 160\%, mainly due to dramatically reduced production levels in East Africa and Latin America [49].

A study conducted by researchers from the Institute of Plant Diseases and Plant Protection and the International Center of Insect Physiology and Ecology in Nairobi used climate models to predict the effects of climate change on the Coffee Berry Borer. The Coffee Berry Borer is forecast to worsen in the current Arabica producing areas of Ethiopia, the Ugandan part of Lake Victoria and Mount Elgon regions, Mount Kenya and the Kenyan side of Mount Elgon and most of Rwanda and Burundi. The research also suggests that the number of Coffee Berry Borer generations per year is set to increase in many Arabica producing areas, even in high altitude areas currently unsuitable for the pest, with serious implications for Arabica production and livelihoods in East Africa. Climate change and its forecasted impact on coffee production will have huge implications for livelihoods and poverty levels throughout the tropics. Most studies agree that climate change will cause more harm to poor communities [50] like small-scale coffee producers because they rely more heavily on natural resources for survival and have little capital to invest in costly adaptation strategies and/or pest and disease management.

The Eastern Africa sub-region is the origin of Arabica coffee, Coffea arabica, and also represents, together with the lowland forests of Western and Central Africa, the primary centre of genetic diversity for Coffea canephora (Robusta coffee being the main sub-type). As would be expected, coffee production is the main-stay of economies of most countries in the sub-region where it also represents a major source of cash income for millions of smallholder families not to mention the large number of workers directly employed in the industry. The sub-region furthermore, produces some of the finest coffees in the world. Production of this coffee, however, may face the greatest challenge from climate change given that both Arabica and Robusta coffee have rather exacting agro-ecological requirements. Due to the impact of climate change, coffee cultivation in Ethiopia for example would have to shift from the lowermost optimal cultivation areas now at $1000 \mathrm{~m}$ to $1800 \mathrm{~m}$ within the next 70 or so years while the optimal coffee area in Oromya, the most important coffee growing region in the country, could be reduced by as much as $30 \%$; not to mention the threat to the already dwindling coffee genetic resources in the country [11]. Coffee farmers need new strategies to combat threats such as the coffee berry borer and require research. The coffee industry has two options, either they start investing in climate research, or they educate the consumers to drink something else [13].

\section{Conclusion}

Although Ethiopia is the homeland for Arabica Coffee and the environmental conditions are suitable for Coffee production, the average national yield is very low. Coffee insect pests constrain the production of expected high 
coffee yield and quality. Coffee berry borer, Hypothenemus hampei Ferrari (Coleoptera: Scolytidae) is one of the major potential insect pest in coffee growing areas of Ethiopia and currently expanding its distribution and attacks coffee plant in major coffee producing areas of Ethiopia. The spread of coffee berry borers to higher altitudes is very bad news for both the coffee farmers and for those of us who absolutely like high quality East African, particularly Ethiopian coffee. Global warming is already affecting the bionomics of arthropods. Detailed studies from the temperate zones on several species report mainly positive effects on insect fitness and distribution range. On the other hand, surprisingly, the potential impact of global warming in tropical insects has only been studied in a few insect pests. The impacts of climate change on coffee production are very specific for each geographic region. Climate change may also lead to a resurgence of certain insect pests on coffee, rising temperatures will increase infestation by the Coffee berry borer (Hypothenemus hampei) particularly where coffee grows without shade and the cropping is continuous throughout the year. Climate change will have an impact on the suitability of Arabica coffee growing areas in Ethiopia. Generally, in the near future the impacts will include traditional areas will no longer be suitable for growing coffee and new agricultural practices will be necessary to adapt to climate change. These will impact negatively on yield, quality as well as change in insect pest patterns. Areas that are currently still suitable for Arabica coffee require adaptation strategies in order to sustain the livelihood of farmers depending on Arabica coffee. The coffee berry borer is already being favored by climate change because the rising temperatures are allowing it to establish in higher altitudes where it was not found before. These changes will likely add to the stresses already facing Ethiopian coffee growers. This paper is not yet conclusive and since there is little information on this important insect pest and its current status. There is a need to investigate further information and researches on biology, host alternation, loss assessment, management approaches, coffee farming systems (practices) and their influences on coffee berry borer prevalence, awareness of farmers about climate change and coffee berry borer, and other related issues. Thus, the frequency and severity of climatic extremes are increasing and making adaptation an absolute necessity through using current information on climate variability to develop long term plans for managing coffee berry borer via reducing the vulnerability of Ethiopian coffee growers continued changes in temperature and rainfall.

\section{References}

[1] Yilma, T., Olana, G. and Zegeye, T. (2000) Some Socio Economic Issue Related to Fungicide Use against CD in Ethiopia. Preceding of Workshop on the Command (CBI) in Ethiopia, Addis Ababa, 13-14 August 1999, 72-84.

[2] CIA (2011) World Factbook. CIA, Washington DC.

[3] Woldemariam, T., Denich, M., Gatzweler, F., Balcha, G. and Tekatay, D. (2008) In Situ Conservation of Genetic Resources of Wild Arabica Coffee in Montane Rain Forest Ethiopia. In: Adugna, G., Shimber, B.B.T., Taye, E. and Kufa, T., Eds., Coffee Diverslly \& Know Ledge, EIRO, Addis Ababa, 29-343.

[4] FDRE (2003) Comprehensive Coffee Development and Marketing Plan. Federal Democratic Republic of Ethiopia, Ministry of Agriculture and Rural Development, Addis Ababa. Translated from Amharic in July (2004) by the Coffee Improvement Programme IV.

[5] Mitchell, H.W. (1985) Cultivation and Harvesting of the Arabica Coffee TREE. In: Clarke, R.J. and Macrae, R., Eds., Coffee Agronomy, Vol. 4, 43-90 pp. Booker Agriculture International Limited, Westport Publishing Company, London, Thame, Oxon., UK), 163-178 pp. IAR, Addis Ababa, Ethiopia.

[6] Abebe, M. (1987) Insect Pests of Coffee with Special Emphasis on Antestia Bug, Antestiopsis intricate. Ethiopia Insect scenes and Applocatopm, 8, 977-980.

[7] FAO (2007) Climate Change and Food Security: A Framework for Action. Report by an Interdepartmental Working Group on Climate Change. FAO, Rome.

[8] IPCC (2007) Climate Change (2007). The Fourth Assessment Report. Impacts, Adaptation and Vulnerability. Cambridge University Press, Cambridge.

[9] FAO (2008) Climate Change and Food Security: A Framework Document. Food and Agriculture Organization of the United Nations. http://www.fao.org/forestry/15538-079b31d45081fe9c3dbc6ff34de4807e4.pdf

[10] Trenberth, K.E., Jones, P.D., Ambenje, P., Bojariu, R., Easterling, D., Klein Tank, A., Parker, D., Rahimzadeh, F., Renwick, J.A., Rusticucci, M., Soden, B. and Zhai, P. (2007) Observations: Surface and Atmospheric Climate Change. In: Solomon, S., Qin, D., Manning, M., Chen, Z., Marquis, M., Averyt, K.B., Tignor, M. and Miller, H.L., Eds., Climate Change 2007: The Physical Science Basis. Contribution of Working Group I to the Fourth Assessment Report of the Intergovernmental Panel on Climate Change, Cambridge University Press, Cambridge, UK and New York, USA.

[11] Jaramillo, J., Chabi-Olaye, A., Kamonjo, C., Jaramillo, A., Vega, F.E., Poehling, H.M. and Borgemeister, C. (2009) 
Thermal Tolerance of the Coffee Berry Borer Hypothenemus hampei: Predictions of Climate Change Impact on a Tropical Insect Pest. PLoS ONE, 4, e6487.

[12] Mendesil, E., Jembere, B. and Seyoum, E. (2003) Occurrence of Coffee Berry Borer Hypothenemus hampei (Ferrari) (Coleoptera: Scolytidae) on Coffea arabica L. in Ethiopia. Ethiopian Journal of Biological Sciences, 2, 61-72.

[13] Westly, E. (2010) Spurred by Warming Climate, Beetles Threaten Coffee Crops. A Freelance Science Writer Based in Brooklyn, New York.

[14] Food and Agriculture Organization of the United Nations. FAOSTAT Data for (91993-2009). Rome.

[15] Technoserv (2011) Photo: Image Used with Permission from Technoserv. http://www.flickr.com/photos/50183375@N08/5546602122/in/photostream/

[16] Amsalu, A. and Ludi, E. (2010) The Effect of Global Coffee Price Changes on Rural Livelihoods and Natural Resource Management in Ethiopia: A Case Study from Jimma Area. NCCR North-South Dialogue 26, Bern.

[17] Senbeta Wakjira, F. (2008) Biodiversity and Ecology of Afromontane Rainforests with wild Coffee arabica L. Populations in Ethiopia. Ph.D. Dissertation, Ecology and Development Series No. 38, Cuviller Verlag, Gottinge, 144 p.

[18] Crown Coffee (2002) Ethiopian Coffee Speciality (Unpublished). Addis Ababa.

[19] Wolde-Sadik, W. and Kebede, K. (2000) Coffee Production System in Ethiopia Addis Ababa. Proceedings of the Workshop Control of Coffee Berry Disease (CBD), IAR (Then Name of EIAR, Ethiopian Institute of Agriculture), Addis Ababa, 13-15 August 1999, 99-106.

[20] Mendesil, E., Abebe, M. and Abdeta, C. (2008) Review of Research on Coffee, Tea and Spices Insect pests in Ethiopia. In: Tadesse, A., Ed., Increasing Crop Production through Improved Plant Protection, Vol. II, PPSE and EARO (Ethiopian Agricultural Research Organization), Addis Ababa, Ethiopia. KGaA. Weinheim, Garmeny, 117-140.

[21] Abebe, M. (2000) Significance of Arthropod Pests of Coffee in Ethiopia. Proceedings of Workshop on the Control of CBD in Ethiopia, IAR, Addis Ababa, 13-15 August 1999, 66-71.

[22] Waterhouse, D.F. and Norries, K.R. (1989) Biological Control Pacific Prospects. Supplement 1. Hypothenemus hampei (Ferrari). Australian Centre for International Agricultural Research, Canberra, 57-75.

[23] Murphy, S.T. and Moore, D. (1990) Biological Control of Coffee Berry Borer, Hypothenemus hampei (Ferrari) (Coleoptera: Scolytidae): Previous Programmes and Possibilities for the Future. Biocontrol News and Information, 11, 107-117.

[24] Baker, P.S. (1984) Some Aspects of the Behaviour of the Coffee Berry Borer in Relation to Its Control in Southern Mexico (Coleoptera: Scolytidae). Folia Entomologica Mexicana, 61, 9-24.

[25] Davidson, A. (1967) The Occurrence of Coffee Berry Borer Hypothenemus (stephanoderis) hampei in Ethiopia. Cafei, 8, 1-3.

[26] Abebe, M. (1998) Further Evidence on the Occurrence of Coffee Berry Borer in Ethiopia. Second Intercontinental Conference on Coffee Berry Borer, Tapachula, 75-76.

[27] Sponagel, K.W. (1994) La brocadel café Hypothenemus hampei en plantaciones de café robusta en la Amazonía Ecuatoriana. Wissenschaftlicher Fachverlag, Giessen, 191 p.

[28] Barrera, J.F. (1994) Dynamique des populations du scolyte des fruits du caféier, Hypothenemus hampei (Coleoptera: Scolytidae), et lute biologique avec le parasitoide Cephalonomia stephanoderis (Hymenoptera: Bethylidae), au Chiapas, Mexique. Ph.D Thesis, Université Paul-Sabatier, Toulouse III, Toulouse, 301 p.

[29] Vega, F.E., Rosenquist, E. and Collins, W. (2003) Global Project Needed to Tackle Coffee Crisis. Nature, 425, 343. http://dx.doi.org/10.1038/425343a

[30] Ortiz-Persichino, C. (1991) Pérdidaspor la brocadel café en el Soconusco, Chiapas. Informetécnico. Unidad de Estudios Economicos y Sociales, Centro de Investigaciones Ecológicasdel Sureste, San Cristóbal de las Casas, Chiapas, $126 \mathrm{p}$.

[31] Damon, A. (2000) A Review of the Biology and Control of the Coffee Berry Borer Hypothenemus hampei (Coleoptera: Scolytidae). Bulletin of Entomological Research, 90, 453-465. http://dx.doi.org/10.1017/S0007485300000584

[32] Guathier, N. (2010) Multiple Cryptic Genetic Units in Hypothenemus hampei (Coleoptera: Scolytinae): Evidence from Microsatellite and Mitochondrial DNA Sequence Data. Biological Journal of the Linnean Society, 101, 113-129. http://dx.doi.org/10.1111/j.1095-8312.2010.01483.x

[33] Assad, E.D., Pinto, H.S., Zullo, J. and Helminsk, A.M. (2004) Climatic Changes Impact in Agroclimatic Zoning of Coffee in Brazil. Pesquisa Agropecuária Brasileira, 39, 1057-1064. http://dx.doi.org/10.1590/S0100-204X2004001100001

[34] Mangina, F.L., Makundi, R.H., Maerere, A.P., Maro, G.P. and Teri, J.M. (2010) Temporal Variations in the Abundance of Three Important Insect Pests of Coffee in Kilimanjaro Region, Tanzania. African Journal of Plant Protection, 
Tanzania publishing House Ltd., Daresealaam.

[35] Davis, A.P., Govaerts, R., Bridson, D.M. and Stoffelen, P. (2006) An Annotated Taxonomic Conspectus of the Genus Coffea (Rubiaceae). Botanical Journal of the Linnean Society, 152, 465-512.

[36] Houghton, J.T., Ding, Y., Griggs, D.J., Noguer, M., van der Linden, P.J., Dai, X., et al. (2001) Climate Change 2001: The Scientific Basis. Cambridge University Press, Cambridge, 769 p.

[37] Hulme, M., Doherty, R., Ngara, T., New, M. and Lister, D. (2001) African Climate Change 1900-2100. Climate Research, 17, 145-168. http://dx.doi.org/10.3354/cr017145

[38] Deutsch, C.A., Tewksbury, J.J., Huey, R.B., Sheldon, K.S., Ghalambor, C.K., Haak, D.C. and Martin, P.R. (2008) Impacts of Climate Warming on Terrestrial Ectotherms across Latitude. Proceedings of the National Academy of Sciences of the United States of America, 105, 6668-6672. http://dx.doi.org/10.1073/pnas.0709472105

[39] Campbell, A., Frazer, B.D., Gilbert, N., Gutierrez, A.P. and Mackauer, M. (1974) Temperature Requirement of Some Aphids and Their Parasites. Journal of Applied Ecology, 11, 431-438. http://dx.doi.org/10.2307/2402197

[40] Vaast, P., Bertrand, B., Perriot, J.J., Guyot, B. and Genard, M. (2006) Fruit Thinning and Shade Improve Bean Characteristics and Beverage Quality of Coffee (Coffea arabica L.) under Optimal Conditions. Journal of the Science of Food and Agriculture, 86, 197-204. http://dx.doi.org/10.1002/jsfa.2338

[41] Kirkpatrick, T.W. (1935) The Climate and Eco-Climates of Coffee Plantations. East African Agricultural Research Station, Amani, Kenya, 66 p.

[42] Ward, N.L. and Masters, G.J. (2007) Linking Climate Change and Species Invasion: An Illustration Using Insect Herbivores. Global Change Biology, 13, 1605-1615. http://dx.doi.org/10.1111/j.1365-2486.2007.01399.x

[43] Kyamanywa, S., Kucel, P., Uringi, N., Kovach, J., Roberts, A. and Erbaugh, M. (2009) Arabica Coffee Pest Profiles in the Mt. Elgon Area of Uganda. Report on Arabica IPM-CRSP Project in Uganda.

[44] Jaramillo, J., Muchugu, E., Vega, F., Davis, A., Borgemeister, C. and Chabi-Olaye, A. (2011) Some Like It Hot: The Influence and Implications of Climate Change on Coffee Berry Borer (Hypothenemus hampei) and Coffee Production in East Africa. PLoS ONE, 6, e24528. http://dx.doi.org/10.1371/journal.pone.0024528

[45] Jaramillo, A. (2005) Andean Climate and Coffee in Colombia. Colombian National Federation of Coffee Growers. Centro Nacional de Investigaciones de Café-Cenicafé, Chinchiná, 192 p. (In Spanish)

[46] International Coffee Organization (ICO) (2009) Climate Change and Coffee. International Coffee Council 103rd Session, London, 23-25 September 2009, 8 p.

[47] Van der Putten, W., Macel, M. and Visser, M.E. (2010) Predicting Species Distribution and Abundance Responses to Climate Change: Why It Is Essential to Include Biotic Interactions across Trophic Levels. Philosophical Transactions of the Royal Society B, 365, 2025-2034. http://dx.doi.org/10.1098/rstb.2010.0037

[48] Tylianakis, J.M., Didham, R.K., Bascompte, J. and Wardle, D.A. (2008) Global Change and Species Interactions in Terrestrial Ecosystems. Ecology Letters, 11, 1351-1363. http://dx.doi.org/10.1111/j.1461-0248.2008.01250.x

[49] Rosenthal, E. (2011) Heat Damages Colombia Coffee, Raising Prices. New York Times, 9 March 2011.

[50] Hope, K.R. (2009) Climate Change and Poverty in Africa. International Journal of Sustainable Development \& World Ecology, 16, 451-461. http://dx.doi.org/10.1080/13504500903354424 
Scientific Research Publishing (SCIRP) is one of the largest Open Access journal publishers. It is currently publishing more than 200 open access, online, peer-reviewed journals covering a wide range of academic disciplines. SCIRP serves the worldwide academic communities and contributes to the progress and application of science with its publication.

Other selected journals from SCIRP are listed as below. Submit your manuscript to us via either submit@scirp.org or Online Submission Portal.
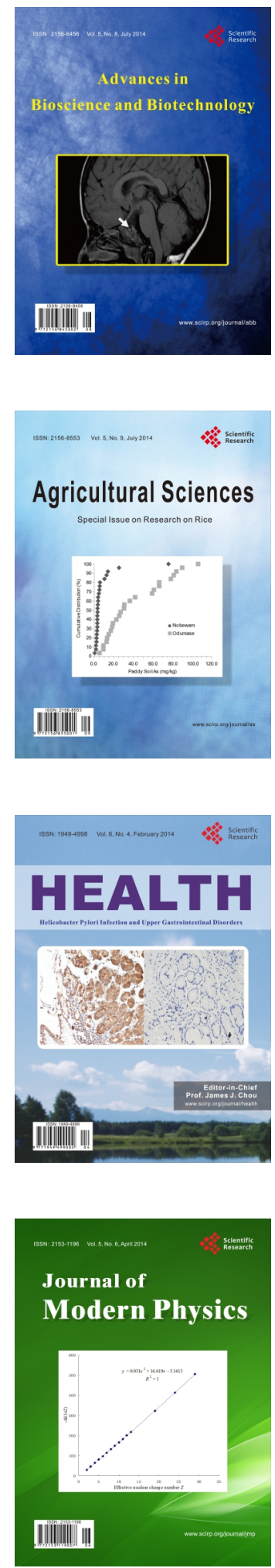
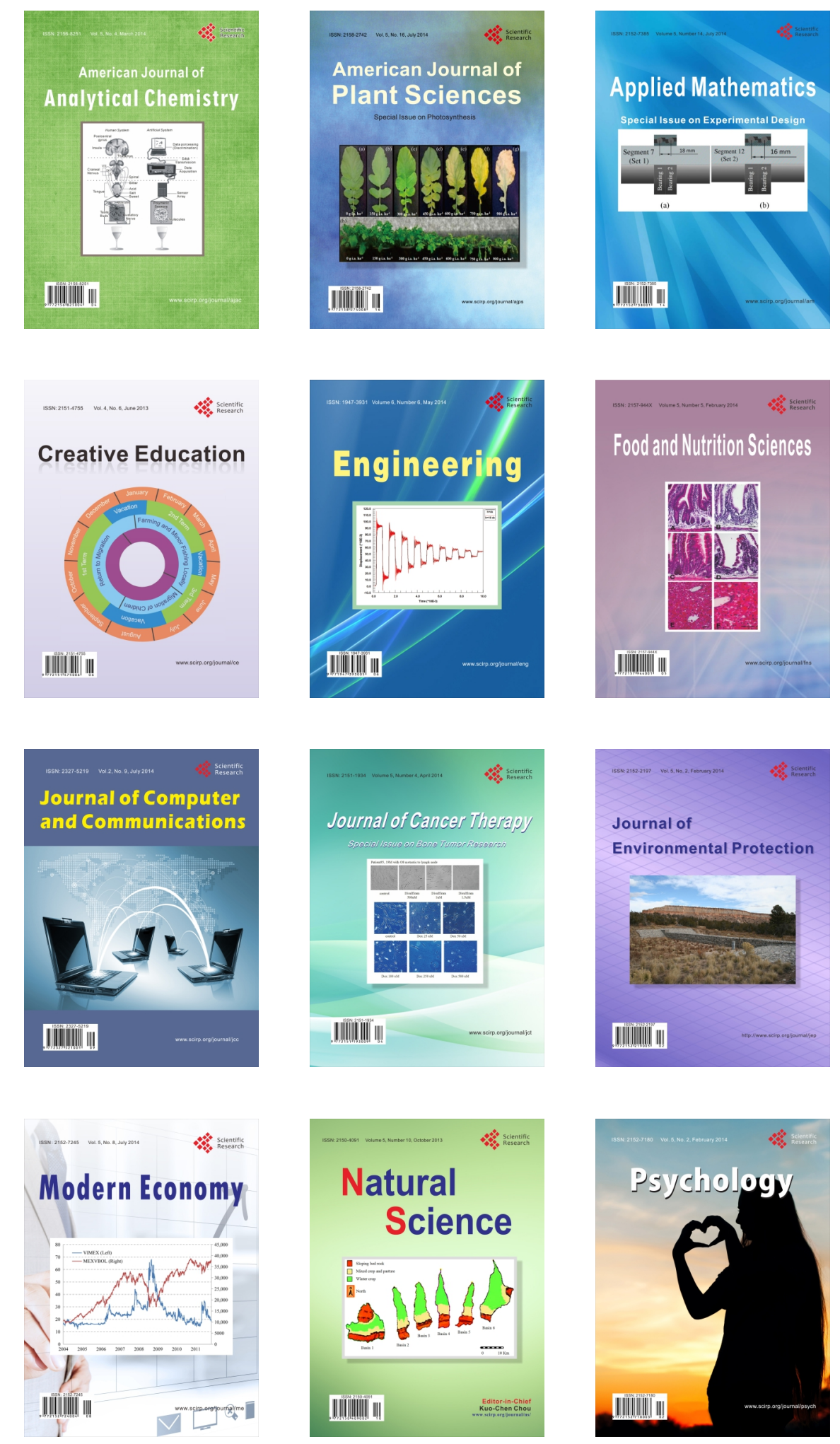